\title{
Naringenin Protects Hepato-Renal Tissues Against Antituberculosis Drugs Induced Toxic Manifestations by Modulating IL-6, IGF-1, CYP2E1, Biochemical and Ultra-Structural Integrity
}

Nisha Sahu

Guru Ghasidas University

Samrat Rakshit

Guru Ghasidas University

Satendra Kumar Nirala

Guru Ghasidas University

Monika Bhadauria ( $\square$ monikabhadauria@rediffmail.com )

Guru Ghasidas University

\section{Research Article}

Keywords: Antituberculosis drugs, Naringenin, Hepato-renal injury, Ultra morphology, Oxidative stress, IL-6, IGF-1.

Posted Date: October 29th, 2021

DOl: https://doi.org/10.21203/rs.3.rs-934724/v1

License: (c) (i) This work is licensed under a Creative Commons Attribution 4.0 International License.

Read Full License 


\section{Abstract}

Adverse drug reactions are unavoidable risk factors allied with use of modern medicines. First-line antituberculosis drugs (ATDs) contribute to diverse pathological complications lead to severe oxidative stress and cause hepato-renal injury. This study was designed to investigate protective potential of naringenin to limit ATDs (combination of pyrazinamide, ethambutol, isoniazid and rifampicin) induced hepato-renal injury. The dose of ATDs was converted from human dose into rat dose and three different doses $(10,20$ and $40 \mathrm{mg} / \mathrm{kg}$ ) of naringenin was administered conjointly through oral route on alternate days for 8 weeks and every Sunday was a rest day. One-way ANOVA $(\mathrm{P} \leq 0.05)$ followed by Tukey's post hoc HSD test determined statistical significance. Results indicated significant increase in IL-6, triglycerides, cholesterol, bilirubin but depletion in IGF-1, albumin and glucose in serum after exposure to ATDs. Lipid peroxidation in microsomes and CYP2E1 enzyme activity was also increased significantly whereas, a severe depletion of endogenous antioxidants including GR, GPx and G-6-PDH was observed. Ultrastructural observations of liver and kidney showed marked deviation in plasma membranes of various cellular and sub-cellular organelles. Conjoint treatment of naringenin counteracted ATDs induced toxic manifestation sy regulating IL-6, IGF-1, biochemical and ultra-structural integrity in a dose dependent manner. Naringenin also inhibited the depletion of CYP2E1 enzyme as it provided help for biotransformation of ATDs. These findings demonstrated that naringenin provided protection against ATDs induced hepato-renal injury by balancing oxidative stress and inflammation via upregulating antioxidant enzymes.

\section{Introduction}

Tuberculosis is one of the top 10 causes of death worldwide (WHO, 2020). The first-line anti tuberculosis drugs (ATDs), the isoniazid, pyrazinamide, rifampicin and ethambutol are administered to patients as single tablet in the first phase for 2 months and in combination (isoniazid+rifampicin) in the second phase for another 4 months (Arbex et al., 2010). Therapy with rifampicin and pyrazinamide increases isoniazid induced liver injury (Chang et al., 2008). Adverse drug reactions (ADRs) due to ATDs may cause skin reaction, gastrointestinal, neurological disorders (Tostmann et al., 2008), hepatotoxicity (Shehu et al., 2017), nephrotoxicity or even death, if not recognized timely (Chang et al., 2014). It is the liver that mainly metabolizes xenobiotics and endogenous molecules in close association with kidney, which performs a number of essential functions, including clearance of endogenous waste products, maintenance of electrolytes and acid-base balance etc. The kidney is continuously exposed to a larger proportion and higher concentration of xenobiotics than other organs and always remains at greater risk of injury (Lock and Reed, 1998). Reactive metabolites, during metabolism or biotransformation weaken the antioxidant defense system resulting in hepatic injury (Attia, 2010). Control on tuberculosis without any side effect of ATDs is still a challenge to medical community. Search for alternative and/ or complementary therapeutic strategies continues to lessen the risk of ATDs induced toxic manifestations in liver and kidney.

Nature is rich with diversified natural compounds that may be explored for potential drugs. Naringenin is a plant bioflavonoid mainly found in grapes, tomatoes and citrus fruits and profoundly helpful to human 
well beings due to its inherent antioxidant potential and excellent bioavailability (Palma-Duran et al., 2015). Its chemical structure has polyphenolic compound with two benzene rings connected together with a heterocyclic pyrone ring (Tripoli et al., 2007) that makes it good antioxidant and potent therapeutic agent. It is utilized as medicines for osteoporosis, growth and cardiovascular maladies, lipid lowering and insulin-like properties, anti-tumor (Sabarinathan et al., 2011), anti-viral (Goldwasser et al., 2010), antidiabetic (Kapoor et al., 2013), anti-inflammatory (Yoshida et al., 2013), hepatoprotective and nephroprotective (Renugadevi and Prabu, 2009), antioxidant (Mershiba et al., 2013), immunomodulatory (Yilma et al., 2013) and neuroprotective properties (Raza et al., 2013).

Previous studies reported that therapy of naringenin maintains level of biomarkers of liver and kidney functions, decreases oxidative stress, increases non enzymatic antioxidant status, decreases histological lesions as well (Sahu et al., 2020). On the basis of this report, it was hypothesized that naringenin therapy may improve enzymatic antioxidants pool as well as normalize synthesis and storage capacity of liver. Thus, present study was undertaken to explore curative effect of naringenin against anti-tuberculosis drugs induced hepato-renal injury considering endogenous antioxidant enzyme, triglycerides and cholesterol, albumin and glucose for synthesis activity, inflammatory and ultra-structural aspects.

\section{Materials And Methods}

\section{Chemicals}

The ATDs (isoniazid, rifampicin, ethambutol and pyrazinamide) were generously obtained from the CIMS, Bilaspur (C.G.). Naringenin and all other chemicals were of pure and analytical grade and procured from standard chemical dealers.

\section{Animals}

Healthy female albino Wistar strain rats weighing $150 \pm 10 \mathrm{~g}$ body weight was used in this study. The animals were housed under standard husbandry conditions (temperature $25 \pm 2{ }^{\circ} \mathrm{C}$ temp, relative humidity $62-72 \%$, light-dark cycle of $14 \mathrm{~h}$ and $10 \mathrm{~h}$ ) and fed on standard pelleted diet and drinking water ad libitum. Experiment was conducted in accordance with the guidelines set by the Committee for the Purpose of Control and Supervision of Experiments on Animals (CPCSEA) India and study design was approved by institutional animal ethics committee (994/Ere/Go/06/CPCSEA).

\section{Study Design}

Animals were divided into seven groups of six animals in each. Group I was treated with vehicle and served as control. Group II was administered with naringenin per se at the dose of $40 \mathrm{mg} / \mathrm{kg}$, orally. Group III to VII were administered with four ATDs namely pyrazinamide, ethambutol, isoniazid and rifampicin with $1 \mathrm{~h}$ of break in between each at the doses of $210,170,85$ and $65 \mathrm{mg} / \mathrm{kg}$ respectively for 8 weeks (3 alternate days in a week) and group III served as experimental control. Animals of groups IV, V and VI 
were given naringenin at the doses of 10, 20 and $40 \mathrm{mg} / \mathrm{kg}$, p.o., respectively for 8 weeks (3 alternate days in a week considering every next day to ATDs exposure). Group VII was treated with silymarin at dose of $50 \mathrm{mg} / \mathrm{kg}$, p.o., as positive control. All the animals were euthanized after $24 \mathrm{~h}$ of the last treatment; blood, liver and kidney were taken out from the animals and stored at $-20^{\circ} \mathrm{C}$ until analyzed.

\section{Serum biochemical assays}

The serum was used for determination of albumin, triglycerides, cholesterol and blood sugar level using diagnostic kits according to the manufacturer's instructions (Erba diagnostics, Germany).

\section{Aniline hydroxylase for CYP2E1 activity}

Aniline hydroxylase (AH) was determined by assessing intensity of blue colored conjugate of phenol with p-amino phenol (PAP) (Kato and Gillette, 1965). Microsomal lipid peroxidation (Sharma and Krishna Murti, 1968) and microsomal protein (Lowry et al., 1951) were also determined.

\section{Tissue biochemical assays}

Hepatic and renal tissues were processed to determine cholesterol (Zlatkis et al., 1953), triglycerides (Neri and Frings, 1973) and total proteins (Lowry et al., 1951).

\section{Antioxidant enzyme activity}

The activities of glutathione peroxidase was analyzed by assessing reduction of NADP ${ }^{+}$to NADPH (Paglia and Valentine, 1967), glutathione reductase was determined by quantifying the amount of NADPH utilized (Tayarani et al., 1989) and glucose-6-phosphatase dehydrogenase was determined by assessing the rate of conversion of NADPH to $\mathrm{NADP}^{+}$(Askar et al., 1996).

\section{Interleukin-6 and insulin like growth factor-1}

Cytokine interlukin-6 (IL-6) and insulin like growth factor-1 (IGF-1) were assessed in serum using ELISA based kits (Ray Biotech, INC, Norcross, GA 30092 USA) and the results were expressed as pg/ml. Entire procedures for assessment were performed following instruction manual of diagnostic kits.

\section{Electron microscopy}

About $1 \mathrm{~mm}^{3}$ pieces of liver and kidney samples were processed for transmission electron microscopy according to previously explained method (Sahu et al., 2018).

\section{Statistical analyses}

The results were presented as mean \pm SE. One-way analysis of variance (ANOVA) was used followed by Tukey's post hoc analysis of honestly significant difference (HSD) at $\mathrm{P} \leq 0.05$ to draw a statistical comparison among different treatment groups (Snedecor and Cochran, 1980). Microsoft office was used to calculate ANOVA, Tukey's post hoc HSD test and percent protection. Following formula was used to calculate percent protection (Rakshit et al., 2021) 


$$
\left(1-\left\{\frac{(\text { Therapy-Control })}{(\text { Toxicant-Control) }}\right\}\right) \times 100
$$

\section{Results}

\section{Serum Biochemical Assays}

Exposure to ATDs for 8 weeks significantly elevated $(P \leq 0.05)$ level of triglyceride, cholesterol and bilirubin whereas, significantly declined $(P \leq 0.05)$ albumin and glucose (Table 1$)$ as compared with control group. Treatment with naringenin at three different doses $(10,20$ and $40 \mathrm{mg} / \mathrm{kg}$ ) shifted biochemical variables towards control. Higher doses, 20 and $40 \mathrm{mg} / \mathrm{kg}$ of naringenin significantly maintained all the serological variables towards control. Tukey's post hoc HSD test revealed that 40 $\mathrm{mg} / \mathrm{kg}$ dose of naringenin caused significant difference in comparison to 10 and $20 \mathrm{mg} / \mathrm{kg}$ dose and showed better protective effects. Treatment with naringenin at $40 \mathrm{mg} / \mathrm{kg}$ dose offered more than $90 \%$ protection in glucose and bilirubin level as well minimum $53 \%$ protection in albumin, triglycerides and approximately $66 \%$ protection in cholesterol level indicating improvement against ATDs toxicity. Efficacy of naringenin was well compared to silymarin positive control group and results clearly showed protective potential of naringenin at par silymarin. 
Table 1

Protective potential of naringenin against ATDs induced deviations in serum biochemistry

\begin{tabular}{|c|c|c|c|c|c|}
\hline & $\begin{array}{l}\text { Albumin } \\
(\mathrm{g} / \mathrm{dl})\end{array}$ & $\begin{array}{l}\text { Glucose } \\
\text { (mg/dl) }\end{array}$ & $\begin{array}{l}\text { Triglyceride } \\
(\mathrm{mg} / \mathrm{dl})\end{array}$ & $\begin{array}{l}\text { Cholesterol } \\
(\mathrm{mg} / \mathrm{dl})\end{array}$ & $\begin{array}{l}\text { Bilirubin } \\
\text { (mg/dl) }\end{array}$ \\
\hline Control & $4.43 \pm 0.32$ & $99.2 \pm 5.17$ & $33.1 \pm 2.28$ & $15.3 \pm 1.11$ & $0.18 \pm 0.01$ \\
\hline Naringenin per se & $4.36 \pm 0.31$ & $99.5 \pm 5.40$ & $34.2 \pm 2.72$ & $15.6 \pm 1.37$ & $0.20 \pm 0.01$ \\
\hline ATD & $\begin{array}{l}3.31 \pm 0.28 \\
*\end{array}$ & $59.7 \pm 4.63 *$ & $74.3 \pm 4.62 *$ & $58.2 \pm 5.52 *$ & $0.43 \pm 0.03 *$ \\
\hline \multirow{2}{*}{$\begin{array}{l}\text { ATD+ Naringenin } \\
(10 \mathrm{mg} / \mathrm{kg})\end{array}$} & $3.36 \pm 0.28$ & $69.1 \pm 4.13^{a}$ & $58.1 \pm 3.15^{\mathrm{a} \Psi}$ & $43.8 \pm 2.81^{\mathrm{a} \psi}$ & $0.24 \pm 0.02^{a \Psi}$ \\
\hline & $05 \%$ & $24 \%$ & $39 \%$ & $34 \%$ & $76 \%$ \\
\hline \multirow{2}{*}{$\begin{array}{l}\text { ATD + Naringenin } \\
(20 \mathrm{mg} / \mathrm{kg})\end{array}$} & $3.73 \pm 0.27$ & $83.4 \pm 6.67^{\Psi}$ & $54.2 \pm 3.36^{\psi}$ & $40.7 \pm 3.30^{a} \Psi$ & $0.22 \pm 0.02^{\psi}$ \\
\hline & $37 \%$ & $60 \%$ & $49 \%$ & $41 \%$ & $84 \%$ \\
\hline \multirow{2}{*}{$\begin{array}{l}\text { ATD+ Naringenin } \\
(40 \mathrm{mg} / \mathrm{kg})\end{array}$} & $3.91 \pm 0.23$ & $98.3 \pm 6.37^{\varphi \Psi}$ & $52.6 \pm 3.56^{a \psi}$ & $29.4 \pm 2.37^{\mathrm{a} \lambda \psi}$ & $0.20 \pm 0.02^{\psi}$ \\
\hline & $53 \%$ & $98 \%$ & $53 \%$ & $66 \%$ & $92 \%$ \\
\hline \multirow{2}{*}{$\begin{array}{l}\text { ATD+ Silymarin (50 } \\
\mathrm{mg} / \mathrm{kg})\end{array}$} & $4.07 \pm 0.24^{\Psi}$ & $90.5 \pm 5.45^{\varphi \Psi}$ & $45.2 \pm 3.03^{\mathrm{a} \varphi} \Psi$ & $18.8 \pm 1.42^{\varphi \lambda \Omega \Psi}$ & $0.19 \pm 0.01^{\varphi} \psi$ \\
\hline & $68 \%$ & $78 \%$ & $71 \%$ & $92 \%$ & $96 \%$ \\
\hline ANOVA & 6.16@ & 15.8@ & 36.2@ & 103.9@ & 57.6@ \\
\hline \multicolumn{6}{|c|}{ 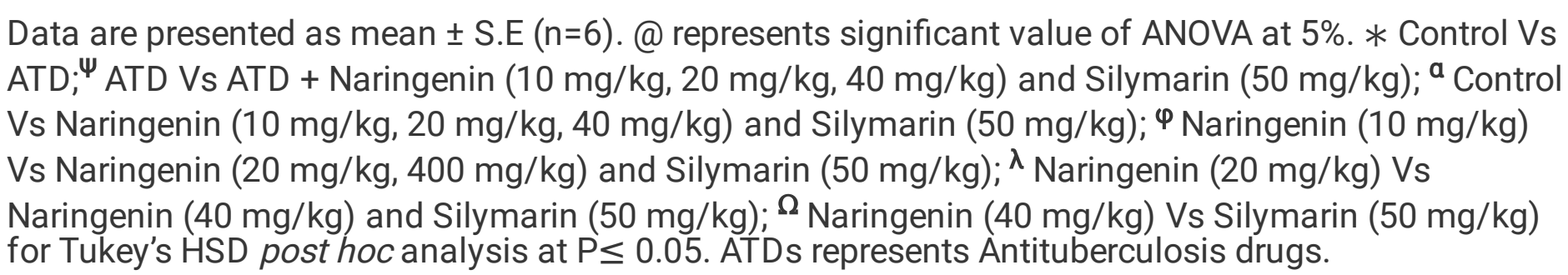 } \\
\hline
\end{tabular}

\section{Aniline Hydroxylase For Cyp2e1 Activity}

Oral administration of ATDs over a period of 8 weeks increased activity of drug metabolizing enzyme, aniline hydroxylase (Fig. 1a) and microsomal lipid peroxidation (Fig. 1b) along with decline in microsomal protein (Fig. 1C). The protein content was significantly decreased whereas, LPO and CYP2E1 activity was increased dramatically. Treatment with naringenin markedly reversed these changes towards their respective control in dose dependent manner. CYP2E1 activity was protected by naringenin in dose dependent manner by $82 \%$ protection at $40 \mathrm{mg} / \mathrm{kg}$ dose. Naringenin at 20 and $40 \mathrm{mg} / \mathrm{kg}$ doses, was able to maintain microsomal LPO and protein, significant difference was observed between both the 
therapeutic groups as revealed by Tukey's post hoc HSD test. The $40 \mathrm{mg} / \mathrm{kg}$ dose of naringenin showed $88 \%$ and $85 \%$ protection in maintaining microsomal LPO and protein respectively.

\section{Tissue lipid profile}

Level of cholesterol and triglyceride was found to be significantly increased $(P \leq 0.05)$ in liver and kidney along with decline in protein after administration of ATDs for 8 weeks as compared with control group (Fig. 2). Tukey's post hoc HSD test revealed that $40 \mathrm{mg} / \mathrm{kg}$ dose of naringenin treated groups was able to maintain triglycerides, cholesterol and protein in hepato-renal tissues better than the lowest dose. Values of control and $40 \mathrm{mg} / \mathrm{kg}$ dose of naringenin were very close to each other. Percent protection analysis confirmed that $40 \mathrm{mg} / \mathrm{kg}$ dose of naringenin provided approximately $93 \%$ protection to hepatic and $61 \%$ protection to renal cholesterol. The $40 \mathrm{mg} / \mathrm{kg}$ dose of naringenin provided above $94 \%$ protection to hepato-renal triglycerides and approximately more than $84 \%$ protection in maintaining hepato-renal proteins respectively. The efficacy of naringenin remained at par the efficacy of silymarin treatment.

\section{Antioxidant enzymes status}

Figure 3 (a-c) illustrates activity of antioxidant enzymes namely glutathione reductase (GR), glutathione peroxidase (GPx) and glucose-6-phosphate dehydrogenase (G6PD) in liver and kidney of various treatment groups. The ATDs administration caused significant $(P \leq 0.05)$ inhibition in the activities of the GR, GPx and G-6-PDH in liver and kidney. Treatment with naringenin significantly up regulated activities of these enzymes in liver and kidney $(P \leq 0.05)$ in dose dependent manner and maintained enzymatic antioxidant integrity towards control. Tukey's post hoc HSD test revealed that, naringenin at 20 and 40 $\mathrm{mg} / \mathrm{kg}$ dose showed better protective efficacy than $10 \mathrm{mg} / \mathrm{kg}$ dose in increasing hepatorenal GR, GPx and G-6-PDH. Percent protection analysis suggested that naringenin at $40 \mathrm{mg} / \mathrm{kg}$ dose showed more than $86 \%$ and $74 \%$ protection in maintaining hepatic and renal GR respectively. Naringenin at $40 \mathrm{mg} / \mathrm{kg}$ dose provided more than $93 \%$ and $86 \%$ protection in maintaining hepatic and renal GPx respectively. However, $40 \mathrm{mg} / \mathrm{kg}$ dose showed restoration of hepato-renal G-6-PDH by providing more than $95 \%$ protection. Results obtained from naringenin treated groups were found very close to silymarin treated group.

Biochemical findings indicated that $40 \mathrm{mg} / \mathrm{kg}$ dose of naringenin maximally protected from ATDs induced organ damage. Thus, only group of $40 \mathrm{mg} / \mathrm{kg}$ dose of naringenin was carried forward to examine IL- 6 and IGF-1 in serum as well as electron microscopy of liver and kidney samples.

\section{Interleukin-6 and insulin like growth factor-1}

There was significant elevation in IL-6 level and decrease in IGF-1 level in serum after ATDs intoxication (Fig. 4a-b). Dose of naringenin at $40 \mathrm{mg} / \mathrm{kg}$ significantly restored these variables towards their respective control $(P \leq 0.05)$ that was well compared with silymarin treated positive control group. Tukey's post hoc HSD test revealed that naringenin at $40 \mathrm{mg} / \mathrm{kg}$ dose showed more than $91 \%$ protection in maintaining IL6 level in serum and approximately 56\% protection in maintaining IGF-1 level in serum.

\section{Electron microscopy observation}


Electron microscopy of liver of control group showed well defined hepatocytes with regular shape nucleus, distinct nuclear membrane, extended endoplasmic reticulum (ER) and numerous mitochondria of various shapes and size (Fig. 5a). Ultra-structural observation of liver of ATDs administered group showed irregular shaped distorted mitochondria (DM), loss of organization of endoplasmic reticulum and presence of lipid droplets (LD) (Fig. $5 \mathrm{~b}$ and c). Treatment with naringenin ( $40 \mathrm{mg} / \mathrm{kg}$ ) showed better formed mitochondria, well-formed nucleus with intact nuclear membrane and obvious nucleolus, heterochromatin, euchromatin and nuclear pore; extensive endoplasmic reticulum, glycogen rosettes and scanty lipid droplets (Fig. $5 \mathrm{~d}$ and e). Treatment with silymarin in positive control group showed wellformed mitochondria, nucleus with intact nuclear membrane, obvious nuclear pore and euchromatin; extensive endoplasmic reticulum and scanty lipid droplets (Fig. 5f).

Ultra-structure of kidney of control group showed well developed elongated mitochondria, nucleus with nuclear membrane, well-formed plasma membrane with extended convolutions (Fig. 6a). Electron micrograph of kidney of ATDs administered group showed renal damage characterized by dilated plasma membrane, irregular and degenerated undulations of plasma membrane and diffusely arranged mitochondria (Fig. 6b and c). Treatment with naringenin ( $40 \mathrm{mg} / \mathrm{kg}$ ) preserved better formed mitochondria arranged between undulation of plasma membrane, and well-formed intact nuclei (Fig. $6 \mathrm{~d}$ and e). Positive control group, treated with silymarin also showed similar effects as exerted by naringenin. Observations indicated well-formed nucleus with intact nuclear membrane, heterochromatin and euchromatin, well-formed plasma membrane and mitochondria of different shape and size (Fig. 6f).

\section{Discussion}

During last few decades, naringenin, has attracted attention of the researchers for its good bioavailability, antioxidant and anti-inflammatory activities and low toxicity (Cavia-Saiz et al., 2010, Martinez et al., 2015). The present study was carried out to explore possibility of naringenin as effective therapeutic agent against ATDs induced hepato-renal toxic manifestations.

Administration of isoniazid, pyrazinamide, rifampicin and ethambutol individually or in combination causes various metabolic and morphologic changes in tissues particularly in liver as it is the main site of biotransformation (Pandit et al., 2012). Any imbalance in the activity of drug metabolizing enzymes shifts equilibrium towards free radical generation that lead to damage DNA to cause mutation, lipid to cause membrane damage, or proteins to alter their activities (Upadhyay et al., 2010). Combination of isoniazid and rifampicin induces oxidative stress to cause hepatic and renal injury ((Attri et al., 2000). Several endogenous antioxidant enzymes play role to prevent and neutralize free radical induced damage. The glutathione reductase reduces oxidized glutathione (GSSH) to reduced glutathione (GSH). Selenoenzyme, glutathione peroxidase reduces $\mathrm{H}_{2} \mathrm{O}_{2}$ and hydroperoxide to non-toxic products (Bais and Saiju, 2014). Glucose-6-phosphate dehydrogenase catalyses synthesis of riboses for nucleic acid production and is the principal intracellular source of NADPH, which keeps GSH at constant level by scavenging ROS. Toxic intermediates of ATDs bring down the activities of these antioxidant enzymes that prompt cells more susceptible to peroxidative damage (Upadhyay et al., 2007). Flavonoids contain 
one or more aromatic hydroxy groups in their chemical structure, responsible for their antioxidant potential and beneficial effects against many diseases (Tungmunnithum et al., 2018). In this investigation, naringenin could restore antioxidant enzymes, reduced oxidative stress and protected membrane damage by scavenging free radicals with the help of three hydroxy groups present at the 4', 5 , and 7 carbons in its structure (Rashmi et al., 2018). Observations of this study were similar to previous reports (Ozkaya et al., 2016).

Oxidative stress (Rahal et al., 2014), infection and injury (Avitsur et al., 2006) induce a cascade of inflammatory reactions with increased production of cytokine, the IL-6. The IL-6 plays a role in development of various diseases, including hypoalbuminemia (Tanaka et al., 2014), liver damage and carcinogenesis (Wieckowska et al., 2008). Growth hormone, produced in the anterior pituitary gland, is released into the blood stream and stimulates liver to produce IGF-1, which is a primary mediator for the effects of growth hormone (Kineman et al., 2018). Both IGF-1 and growth hormone act together to promote growth by exerting growth-promoting effects on skeletal muscle, cartilage, bone, liver, kidney, nerve, skin, hematopoietic, and lung cells (Wit and Camacho-Hübner, 2011) and regulate metabolic function in adults (Clemmons, 2012). In addition to insulin-like effects, IGF-1 also regulates cellular DNA synthesis (Yakar et al., 2002). Oxidative stress resulted from biotransformation of ATDs increased level of IL- 6 along with decrease in IGF-1. Naringenin acted as anti-inflammatory agent by reducing the production of pro-inflammatory cytokine through various mechanisms (Oztürk et al., 2000). Naringenin also has ability to enhance the IGF-1 receptor mediated antioxidant defense against various toxicants (Tseng et al., 2021). These mechanisms brought level of IL-6 and IGF-1 towards their respective control with structural and functional improvement in hepatic and renal tissues.

Albumin, serves a wide-range of functions, including transportation of hormones and bilirubin acts as binding agent for transporting many exogenous and endogenous compounds in circulatory system (Zheng et al., 2014). The ATDs induced hypersensitivity reactions along with hypoalbuminemia and hypoglycemia that signify life-threatening hepatic damage (Arbex et al., 2010). Rifampicin induced conjugated hyperbilirubinemia by hampering excretion of bilirubin through inhibiting bile salt exporter pump (Byrne et al., 2002). Exposure to ATDs increased triglycerides and cholesterol in serum due to severe disruption in cellular metabolism and function (Mishra et al., 2018). The ATDs administration causes hyperlipidemia, which could disrupt membrane fluidity (Reddy et al., 2013). The ATDs disrupt hepatic and renal phospholipids and protein synthesis due to fatty accumulation in these organs (Sahu et al., 2018). Thus, pathogenesis in hepatic and renal tissues could be multi-factorial, reflecting derangement in complex biosynthetic, catabolic and enzymatic pathways and lipoprotein metabolism (Santhosh et al., 2006). Naringenin, defended albumins, lipids and other important biomolecules from being oxidized or destroyed by oxidative stress (Priscilla et al., 2015) and could maintain biochemical integrity in favor of regular functioning.

Antituberculosis drugs are bio transformed by many drug metabolizing enzymes and activation in CYP2E1 is associated with susceptibility to ATDs induced liver injury (Zaverucha-do-Valle et al., 2014). Isoniazid and its metabolite hydrazine mainly induce enzymes of CYP2E1 group (Huang et al., 2003) that 
severely cause hepatotoxicity. Enhanced activity of aniline hydroxylase led to excessive buildup of reactive metabolites within the hepato-renal tissues, which favored an oxidative stress in these organs. Damage to cellular endoplasmic reticulum and mitochondria due to reactive metabolites of ATDs further disrupted drug metabolizing ability of the liver and kidney. Naringenin could suppress oxidative stress by up regulating glutathione reductase, glutathione peroxidase and glucose-6-phosphate dehydrogenase and inhibiting microsomal lipid peroxidation, which subsequently helped in modulation of drug metabolizing enzymes of CYP2E1 group. Diminished oxidative stress could also lead to integrity of other studied cellular biochemical endpoints.

Deviation from regular level of hepato-renal marker enzymes signifies damage in structural integrity of liver and kidney tissues as these enzymes are cytoplasmic in location and released into circulation as indicator of cellular damage (Bhadauria et al., 2007). Exposure to ATDs has been reported to induce hepatic and renal injury by disrupting several cellular features (Jaswal et al., 2013). In this study, naringenin maintained ultra-structural integrity of liver and kidney probably by reducing stress on mitochondria, endoplasmic reticulum and nucleus; thus, showed healing effects by suppressing inflammation and cellular senescence, regulating DNA synthesis, improving cellular growth or regeneration in hepatic and renal tissues (Hunt et al., 2019) similar to previous reports (Mershiba et al., 2013).

\section{Conclusion}

Findings of this research exhibited that treatment with naringenin at doses of 20 and $40 \mathrm{mg} / \mathrm{kg}$ has potential to protect hepato-renal tissues from ATDs induced toxic manifestations by modulating IL-6, IGF1, CYP2E1, antioxidant enzymes, biochemical and ultra-structural integrity; however, it may further be verified with more advanced endpoints to affirm this fact.

\section{Declarations}

Author contributions NS and MB conceived and designed research study. NS and SR conducted experiments under the supervision of MB and SKN. MB and SKN analyzed data. NS wrote the manuscript. SKN and MB edited the manuscript and handled reviewer's comments. All the authors read and approved the manuscript and all data were generated in-house and that no paper mill was used.

Funding: The research work was financially supported by University Grants Commission, New Delhi [(F42520/2013(SR) dated 23-03-2013] sanctioned to Dr. Monika Bhadauria.

Acknowledgments: Chhattisgarh Institute of Medical Sciences (CIMS), Bilaspur generously provided antituberculosis drugs for conducting experiments. Technical support was extended from All India Institute of Medical Sciences (AlIMS), New Delhi for electron microscopy.

Compliance with ethical standards All the experiments were held in accordance with the guidelines set by the Committee for the Purpose of Control and Supervision of Experiments on Animals (CPCSEA) India. 
Study design was approved by institutional animal ethics committee (994/Ere/Go/06/CPCSEA).

Conflicts of interest: The authors hold no conflict of interest on any issue from this study.

\section{References}

1. Arbex MA, Varella Mde C, Siqueira HR, Mello FA (2010) Antituberculosis drugs: drug interactions, adverse effects, and use in special situations. Part 1: first-line drugs. J Bras Pneumol 36:626-640

2. Askar MA, Sumathy K, Baquer NZ (1996) Regulation and properties of purified glucose-6-phosphate dehydrogenase from rat brain. Indian J Biochem Biophys 33:512-518

3. Attia SM (2010) Deleterious effects of reactive metabolites. Oxid Med Cell Longev 3:238-253

4. Attri S, Rana SV, Vaiphei K, Sodhi CP, Katyal R, Goel RC, Nain CK, Singh K (2000) Isoniazid- and rifampicin-induced oxidative hepatic injury--protection by N-acetylcysteine. Hum Exp Toxicol 19:517522

5. Avitsur R, Hunzeker J, Sheridan JF (2006) Role of early stress in the individual differences in host response to viral infection. Brain Behav Immun 20:339-348

6. Bais B, Saiju P (2014) Ameliorative effect of Leucas cephalotes extract on isoniazid and rifampicin induced hepatotoxicity. Asian Pacific Journal of Tropical Biomedicine 4:S633-S638

7. Bhadauria M, Nirala SK, Shukla S (2007) Propolis protects CYP 2E1 enzymatic activity and oxidative stress induced by carbon tetrachloride. Mol Cell Biochem 302:215-224

8. Byrne JA, Strautnieks SS, Mieli-Vergani G, Higgins CF, Linton KJ, Thompson RJ (2002) The human bile salt export pump: characterization of substrate specificity and identification of inhibitors. Gastroenterology 123:1649-1658

9. Cavia-Saiz M, Busto MD, Pilar-Izquierdo MC, Ortega N, Perez-Mateos M, Muñiz P (2010) Antioxidant properties, radical scavenging activity and biomolecule protection capacity of flavonoid naringenin and its glycoside naringin: a comparative study. J Sci Food Agric 90:1238-1244

10. Chang CH, Chen YF, Wu VC, Shu CC, Lee CH, Wang JY, Lee LN, Yu CJ (2014) Acute kidney injury due to anti-tuberculosis drugs: a five-year experience in an aging population. BMC Infect Dis 14:23

11. Chang KC, Leung CC, Yew WW, Lau TY, Tam CM (2008) Hepatotoxicity of pyrazinamide: cohort and case-control analyses. Am J Respir Crit Care Med 177:1391-1396

12. Clemmons DR (2012) Metabolic actions of insulin-like growth factor-l in normal physiology and diabetes. Endocrinol Metab Clin North Am 41:425-443. vii-viii

13. Goldwasser J, Cohen PY, Yang E, Balaguer P, Yarmush ML, Nahmias Y (2010) Transcriptional regulation of human and rat hepatic lipid metabolism by the grapefruit flavonoid naringenin: role of PPARalpha, PPARgamma and LXRalpha. PLoS ONE 5:e12399

14. Huang YS, Chern HD, Su WJ, Wu JC, Chang SC, Chiang CH, Chang FY, Lee SD (2003) Cytochrome P450 2E1 genotype and the susceptibility to antituberculosis drug-induced hepatitis. Hepatology $37: 924-930$ 
15. Hunt NJ, Kang SWS, Lockwood GP, Le Couteur DG, Cogger VC (2019) Hallmarks of Aging in the Liver. Comput Struct Biotechnol J 17:1151-1161

16. Jaswal A, Sinha N, Bhadauria M, Shrivastava S, Shukla S (2013) Therapeutic potential of thymoquinone against anti-tuberculosis drugs induced liver damage. Environ Toxicol Pharmacol 36:779-786

17. Kapoor R, Rizvi F, Kakkar P (2013) Naringenin prevents high glucose-induced mitochondria-mediated apoptosis involving AIF, Endo-G and caspases. Apoptosis 18:9-27

18. Kato R, Gillette JR (1965) Sex differences in the effects of abnormal physiological states on the metabolism of drugs by rat liver microsomes. J Pharmacol Exp Ther 150:285-291

19. Kineman RD, Del Rio-Moreno M, Sarmento-Cabral A (2018) 40 YEARS of IGF1: Understanding the tissue-specific roles of IGF1/IGF1R in regulating metabolism using the Cre/loxP system. J Mol Endocrinol 61:T187-t198

20. Lock EA, Reed CJ (1998) Xenobiotic metabolizing enzymes of the kidney. Toxicol Pathol 26:18-25

21. Lowry OH, Rosebrough NJ, Farr AL, Randall RJ (1951) Protein measurement with the Folin phenol reagent. J Biol Chem 193:265-275

22. Martinez RM, Pinho-Ribeiro FA, Steffen VS, Caviglione CV, Vignoli JA, Barbosa DS, Baracat MM, Georgetti SR, Verri WA Jr, Casagrande R (2015) Naringenin Inhibits UVB Irradiation-Induced Inflammation and Oxidative Stress in the Skin of Hairless Mice. J Nat Prod 78:1647-1655

23. Mershiba SD, Dassprakash MV, Saraswathy SD (2013) Protective effect of naringenin on hepatic and renal dysfunction and oxidative stress in arsenic intoxicated rats. Mol Biol Rep 40:3681-3691

24. Mishra G, Chandra HK, Sahu N, Nirala SK, Bhadauria M (2018) Ameliorative effect of Pergularia daemia (Forssk.) Chiov. leaves extract against anti-tuberculosis drugs induced liver injury in rats. Asian Pac J Trop Med 11:518

25. Neri BP, Frings CS (1973) Improved method for determination of triglycerides in serum. Clin Chem 19:1201-1202

26. Ozkaya A, Sahin Z, Dag U, Ozkaraca M (2016) Effects of Naringenin on Oxidative Stress and Histopathological Changes in the Liver of Lead Acetate Administered Rats. J Biochem Mol Toxicol 30:243-248

27. Oztürk F, Kurt E, Cerçi M, Emiroglu L, Inan U, Türker M, Ilker S (2000) The effect of propolis extract in experimental chemical corneal injury. Ophthalmic Res 32:13-18

28. Paglia DE, Valentine WN (1967) Studies on the quantitative and qualitative characterization of erythrocyte glutathione peroxidase. J Lab Clin Med 70:158-169

29. Palma-Duran SA, Caire-Juvera G, Robles-Burgeño Mdel R, Ortega-Vélez MI, Gutiérrez-Coronado Mde L, Almada Mdel C, Chávez-Suárez K, Campa-Siqueiros M, Grajeda-Cota P, Saucedo-Tamayo Mdel S, Valenzuela-Quintanar Al (2015) Serum levels of phytoestrogens as biomarkers of intake in Mexican women. Int J Food Sci Nutr 66:819-825

30. Pandit A, Sachdeva T, Bafna PJJAPS (2012) Drug-induced hepatotoxicity: a review. 2:233-243 
31. Priscilla DH, Jayakumar M, Thirumurugan KJjoff (2015) Flavanone naringenin: An effective antihyperglycemic and antihyperlipidemic nutraceutical agent on high fat diet fed streptozotocin induced type 2 diabetic rats. 14:363-373

32. Rahal A, Kumar A, Singh V, Yadav B, Tiwari R, Chakraborty S, Dhama K (2014) Oxidative stress, prooxidants, and antioxidants: the interplay. Biomed Res Int 2014: 761264

33. Rakshit S, Shukla P, Verma A, Kumar Nirala S, Bhadauria M (2021) Protective role of rutin against combined exposure to lipopolysaccharide and D-galactosamine-induced dysfunctions in liver, kidney, and brain: Hematological, biochemical, and histological evidences. J Food Biochem 45:e13605

34. Rashmi R, Bojan Magesh S, Mohanram Ramkumar K, Suryanarayanan S, Venkata SubbaRao M (2018) Antioxidant Potential of Naringenin Helps to Protect Liver Tissue from Streptozotocin-Induced Damage. Rep Biochem Mol Biol 7:76-84

35. Raza SS, Khan MM, Ahmad A, Ashafaq M, Islam F, Wagner AP, Safhi MM, Islam F (2013) Neuroprotective effect of naringenin is mediated through suppression of NF-KB signaling pathway in experimental stroke. Neuroscience 230:157-171

36. Reddy GJ, Reddy VP, Sreepavani M, Rajaram C, Kumar SN, Kanhere RS (2013) Evaluation of hepatoprotective potential of ethanolic extract of Ixora pavetta against isoniazid and rifampicin induced hepatotoxicity in rats. Drug invention today 5:201-206

37. Renugadevi J, Prabu SM (2009) Naringenin protects against cadmium-induced oxidative renal dysfunction in rats. Toxicology 256:128-134

38. Sabarinathan D, Mahalakshmi P, Vanisree AJ (2011) Naringenin, a flavanone inhibits the proliferation of cerebrally implanted C6 glioma cells in rats. Chem Biol Interact 189:26-36

39. Sahu N, Mishra G, Chandra HK, Nirala SK, Bhadauria M (2018) Propolis modulates cellular biochemistry, antioxidants, cytokine profile, histological and ultra-morphological status against antituberculosis drugs induced hepatic injury. Asian Pac J Trop Med 11:609

40. Sahu N, Mishra G, Chandra HK, Nirala SK, Bhadauria M (2020) Naringenin mitigates antituberculosis drugs induced hepatic and renal injury in rats. J Tradit Complement Med 10:26-35

41. Santhosh S, Sini TK, Anandan R, Mathew PT (2006) Effect of chitosan supplementation on antitubercular drugs-induced hepatotoxicity in rats. Toxicology 219:53-59

42. Sharma SK, Krishna Murti CR (1968) Production of lipid peroxides by brain. J Neurochem 15:147149

43. Shehu Al, Ma X, Venkataramanan R (2017) Mechanisms of Drug-Induced Hepatotoxicity. Clin Liver Dis 21:35-54

44. Snedecor GW, Cochran WG (1980) Statistical methods. lowa state university press, Ames lowa

45. Tanaka T, Narazaki M, Kishimoto T (2014) IL-6 in inflammation, immunity, and disease. Cold Spring Harb Perspect Biol 6:a016295

46. Tayarani I, Cloëz I, Clément M, Bourre JM (1989) Antioxidant enzymes and related trace elements in aging brain capillaries and choroid plexus. J Neurochem 53:817-824 
47. Tostmann A, Boeree MJ, Aarnoutse RE, de Lange WC, van der Ven AJ, Dekhuijzen R (2008) Antituberculosis drug-induced hepatotoxicity: concise up-to-date review. J Gastroenterol Hepatol 23:192-202

48. Tripoli E, La Guardia M, Giammanco S, Di Majo D, Giammanco MJFc (2007) Citrus flavonoids: Molecular structure, biological activity and nutritional properties: A review. 104: 466-479

49. Tseng YT, Hsu HT, Lee TY, Chang WH, Lo YC (2021) Naringenin, a dietary flavanone, enhances insulin-like growth factor 1 receptor-mediated antioxidant defense and attenuates methylglyoxalinduced neurite damage and apoptotic death. Nutr Neurosci 24:71-81

50. Tungmunnithum D, Thongboonyou A, Pholboon A, Yangsabai A (2018) Flavonoids and Other Phenolic Compounds from Medicinal Plants for Pharmaceutical and Medical Aspects: An Overview. Medicines (Basel) 5

51. Upadhyay G, Kumar A, Singh MP (2007) Effect of silymarin on pyrogallol- and rifampicin-induced hepatotoxicity in mouse. Eur J Pharmacol 565:190-201

52. Upadhyay G, Tiwari MN, Prakash O, Jyoti A, Shanker R, Singh MP (2010) Involvement of multiple molecular events in pyrogallol-induced hepatotoxicity and silymarin-mediated protection: evidence from gene expression profiles. Food Chem Toxicol 48:1660-1670

53. WHO (2020) Global tuberculosis report 2020: executive summary

54. Wieckowska A, Papouchado BG, Li Z, Lopez R, Zein NN, Feldstein AE (2008) Increased hepatic and circulating interleukin-6 levels in human nonalcoholic steatohepatitis. Am J Gastroenterol 103:13721379

55. Wit JM, Camacho-Hübner C (2011) Endocrine regulation of longitudinal bone growth. Endocr Dev 21:30-41

56. Yakar S, Rosen CJ, Beamer WG, Ackert-Bicknell CL, Wu Y, Liu JL, Ooi GT, Setser J, Frystyk J, Boisclair YR, LeRoith D (2002) Circulating levels of IGF-1 directly regulate bone growth and density. J Clin Invest 110:771-781

57. Yilma AN, Singh SR, Morici L, Dennis VA (2013) Flavonoid naringenin: a potential immunomodulator for Chlamydia trachomatis inflammation. Mediators Inflamm 2013: 102457

58. Yoshida H, Watanabe W, Oomagari H, Tsuruta E, Shida M, Kurokawa M (2013) Citrus flavonoid naringenin inhibits TLR2 expression in adipocytes. J Nutr Biochem 24:1276-1284

59. Zaverucha-do-Valle C, Monteiro SP, El-Jaick KB, Rosadas LA, Costa MJ, Quintana MS, de Castro L (2014) The role of cigarette smoking and liver enzymes polymorphisms in anti-tuberculosis druginduced hepatotoxicity in Brazilian patients. Tuberculosis (Edinb) 94:299-305

60. Zheng YR, Suntharalingam K, Johnstone TC, Yoo H, Lin W, Brooks JG, Lippard SJ (2014) Pt(IV) prodrugs designed to bind non-covalently to human serum albumin for drug delivery. J Am Chem Soc 136:8790-8798

61. Zlatkis A, Zak B, Boyle AJ (1953) A new method for the direct determination of serum cholesterol. J Lab Clin Med 41:486-492 
Fig. 1.

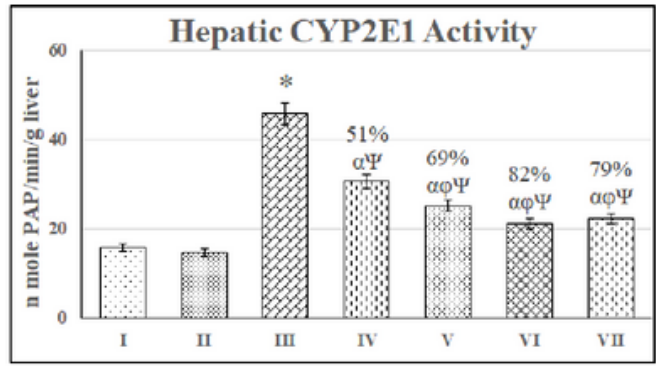

(a)

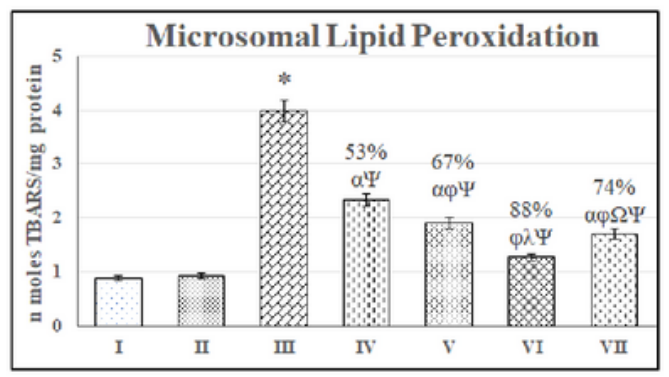

(b)

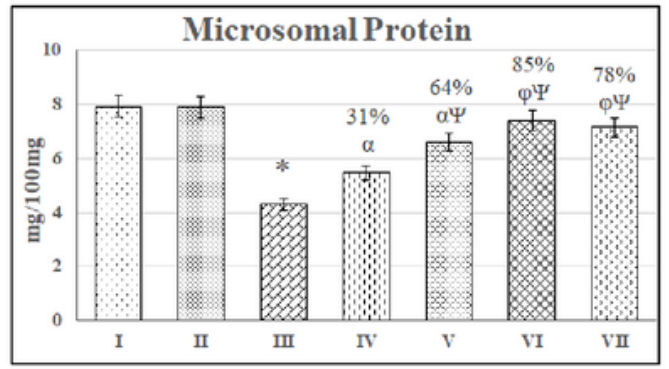

(c)

Fig. 1. (a-c). Therapeutic effect of naringenin on microsomal lipid peroxidation, protein and aniline hydroxylase.

Data are presented as mean \pm S.E $(n=6)$. @ represents significant value of ANOVA at $5 \%$. * Control Vs ATD; ${ }^{\Psi}$ ATD

Vs ATD + Naringenin $(10 \mathrm{mg} / \mathrm{kg}, 20 \mathrm{mg} / \mathrm{kg}, 40 \mathrm{mg} / \mathrm{kg})$ and Silymarin $(50 \mathrm{mg} / \mathrm{kg}) ;{ }^{\alpha}$ Control Vs Naringenin $(10 \mathrm{mg} / \mathrm{kg}$, $20 \mathrm{mg} / \mathrm{kg}, 40 \mathrm{mg} / \mathrm{kg}$ ) and Silymarin $(50 \mathrm{mg} / \mathrm{kg}) ;{ }^{\bullet}$ Naringenin $(10 \mathrm{mg} / \mathrm{kg})$ Vs Naringenin $(20 \mathrm{mg} / \mathrm{kg}, 400 \mathrm{mg} / \mathrm{kg})$ and Silymarin $(50 \mathrm{mg} / \mathrm{kg}) ;{ }^{\lambda}$ Naringenin $(20 \mathrm{mg} / \mathrm{kg})$ Vs Naringenin $(40 \mathrm{mg} / \mathrm{kg})$ and Silymarin $(50 \mathrm{mg} / \mathrm{kg}) ; \quad$ Naringenin $(40 \mathrm{mg} / \mathrm{kg}$ ) Vs Silymarin ( $50 \mathrm{mg} / \mathrm{kg}$ ) for Tukey's HSD post hoc analysis at $\mathrm{P} \leq 0.05$. ATDs represents Antituberculosis drugs. $\mathrm{I}=$ Control, $\mathrm{II}=$ Naringenin $40 \mathrm{mg} / \mathrm{kg}, \mathrm{III}=\mathrm{ATD}, \mathrm{IV}=\mathrm{ATD}+$ Naringenin $10 \mathrm{mg} / \mathrm{kg}, \mathrm{V}=\mathrm{ATD}+\mathrm{Naringenin}$ $20 \mathrm{mg} / \mathrm{kg}, \mathrm{VI}=\mathrm{ATD}+$ Naringenin $40 \mathrm{mg} / \mathrm{kg}, \mathrm{VII}=\mathrm{ATD}+$ Silymarin $50 \mathrm{mg} / \mathrm{kg}$. F variance of CYP2E1 activity = $73.3^{\circ}$, microsomal lipidperoxidation $=123.3^{\circ}$, microsomal protein $=18.7^{\oplus}$.

\section{Figure 1}

"See image above for figure legend" 
Fig. 2.

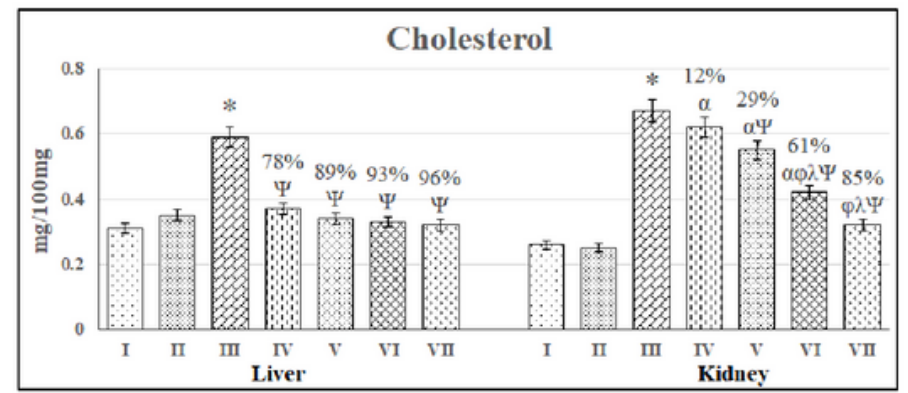

(a)

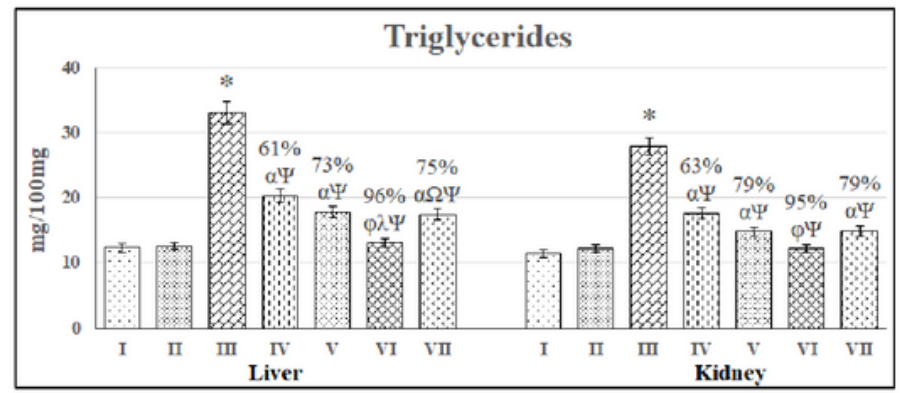

(b)

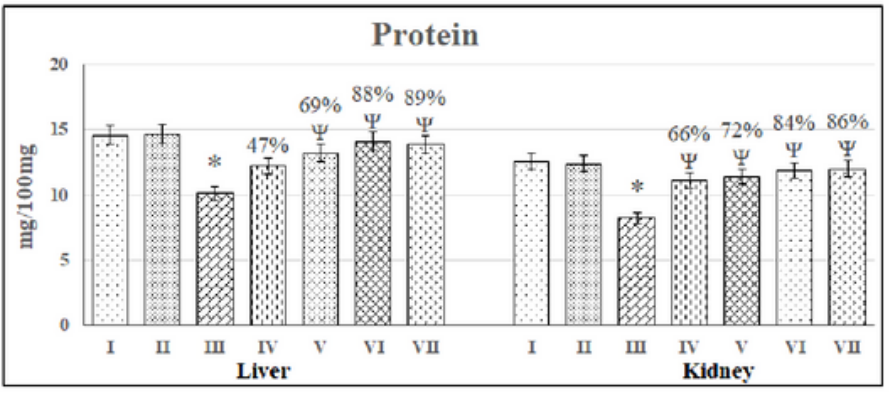

(c)

Fig. 2. (a-c). Effects of ATDs and naringenin on tissue biochemistry.

Data are presented as mean \pm S.E ( $n=6$ ). @ represents significant value of ANOVA at 5\%. * Control Vs ATD; ${ }^{\Psi}$ ATD Vs ATD + Naringenin $(10 \mathrm{mg} / \mathrm{kg}, 20 \mathrm{mg} / \mathrm{kg}, 40 \mathrm{mg} / \mathrm{kg})$ and Silymarin $(50 \mathrm{mg} / \mathrm{kg}) ;{ }^{\alpha}$ Control Vs Naringenin $(10 \mathrm{mg} / \mathrm{kg}$, $20 \mathrm{mg} / \mathrm{kg}, 40 \mathrm{mg} / \mathrm{kg})$ and Silymarin $(50 \mathrm{mg} / \mathrm{kg}) ;{ }^{\oplus}$ Naringenin $(10 \mathrm{mg} / \mathrm{kg}) \mathrm{Vs}$ Naringenin $(20 \mathrm{mg} / \mathrm{kg}, 400 \mathrm{mg} / \mathrm{kg})$ and Silymarin $(50 \mathrm{mg} / \mathrm{kg}) ;{ }^{\lambda}$ Naringenin $(20 \mathrm{mg} / \mathrm{kg})$ Vs Naringenin $(40 \mathrm{mg} / \mathrm{kg})$ and Silymarin $(50 \mathrm{mg} / \mathrm{kg}) ; \quad$ Naringenin $(40 \mathrm{mg} / \mathrm{kg})$ Vs Silymarin $(50 \mathrm{mg} / \mathrm{kg})$ for Tukey's HSD post hoc analysis at $\mathrm{P} \leq 0.05$. ATDs represents Antituberculosis drugs. I = Control, II = Naringenin $40 \mathrm{mg} / \mathrm{kg}, \mathrm{III}=\mathrm{ATD}, \mathrm{IV}=\mathrm{ATD}+\mathrm{Naringenin} 10 \mathrm{mg} / \mathrm{kg}, \mathrm{V}=\mathrm{ATD}+\mathrm{Naringenin}$ $20 \mathrm{mg} / \mathrm{kg}, \mathrm{VI}=\mathrm{ATD}+$ Naringenin $40 \mathrm{mg} / \mathrm{kg}$, VII = ATD + Silymarin $50 \mathrm{mg} / \mathrm{kg} . \mathrm{F}$ variance of Cholesterol (hepatic $=30.8^{\Theta}$, renal $=64.7^{\oplus}$ ), triglyceride $\left(\right.$ hepatic $=67.4^{\oplus}$, renal $=55.1^{\oplus}$ ), protein $\left(\right.$ hepatic $=6.94^{\Theta}$, renal $=7.98^{\oplus}$ ).

\section{Figure 2}

\section{"See image above for figure legend"}


Fig. 3.

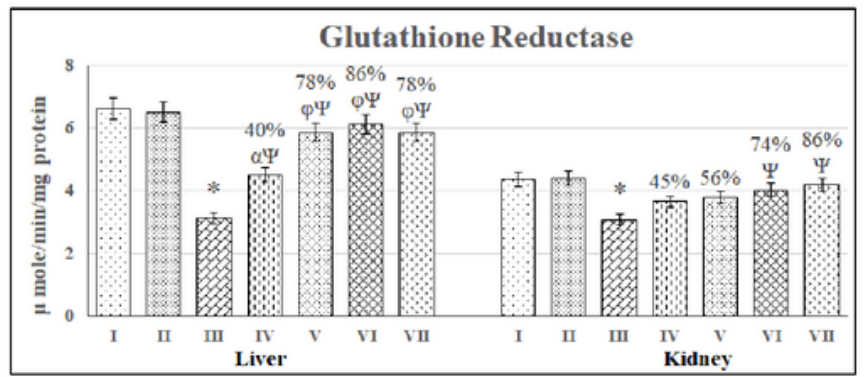

(a)

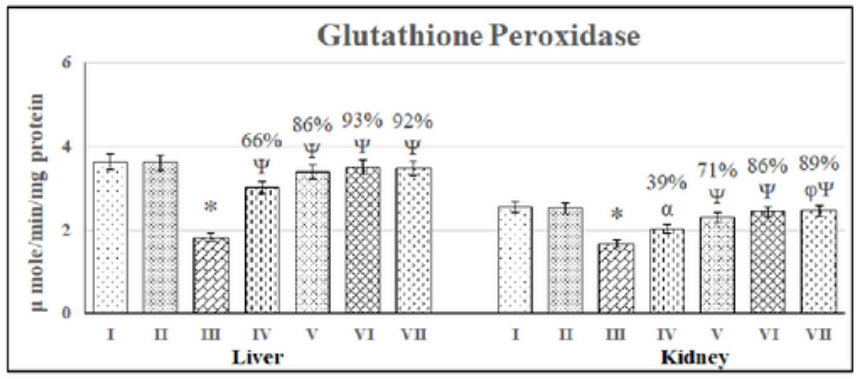

(b)

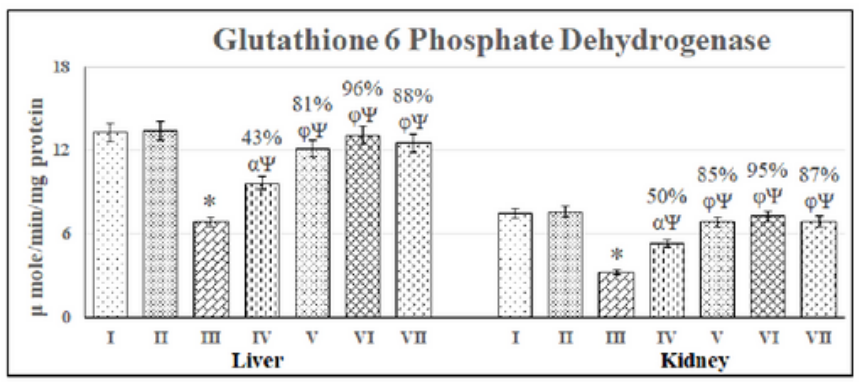

(c)

Fig. 3. (a-c). Protective role of naringenin on endogenous antioxidant enzymes.

Data are presented as mean \pm S.E $(\mathrm{n}=6)$. @ represents significant value of ANOVA at $5 \%$. Control Vs ATD; ${ }^{\mathbf{T}}$ ATD Vs ATD + Naringenin $(10 \mathrm{mg} / \mathrm{kg}, 20 \mathrm{mg} / \mathrm{kg}, 40 \mathrm{mg} / \mathrm{kg})$ and Silymarin $(50 \mathrm{mg} / \mathrm{kg}) ;{ }^{\alpha}$ Control Vs Naringenin $(10 \mathrm{mg} / \mathrm{kg}$, $20 \mathrm{mg} / \mathrm{kg}, 40 \mathrm{mg} / \mathrm{kg}$ ) and Silymarin $(50 \mathrm{mg} / \mathrm{kg})$; Naringenin $(10 \mathrm{mg} / \mathrm{kg}) \mathrm{Vs}$ Naringenin $(20 \mathrm{mg} / \mathrm{kg}, 400 \mathrm{mg} / \mathrm{kg})$ and Silymarin $(50 \mathrm{mg} / \mathrm{kg}) ; \lambda$ Naringenin $(20 \mathrm{mg} / \mathrm{kg})$ Vs Naringenin $(40 \mathrm{mg} / \mathrm{kg})$ and Silymarin $(50 \mathrm{mg} / \mathrm{kg}) ;$ Naringenin $(40 \mathrm{mg} / \mathrm{kg}$ ) Vs Silymarin ( $50 \mathrm{mg} / \mathrm{kg}$ ) for Tukey's HSD post hoc analysis at $\mathrm{P} \leq 0.05$. ATDs represents Antituberculosis drugs. $\mathrm{I}=\mathrm{Control}, \mathrm{II}=\mathrm{Naringenin} 40 \mathrm{mg} / \mathrm{kg}, \mathrm{III}=\mathrm{ATD}, \mathrm{IV}=\mathrm{ATD}+\mathrm{Naringenin} 10 \mathrm{mg} / \mathrm{kg}, \mathrm{V}=\mathrm{ATD}+\mathrm{Naringenin}$ $20 \mathrm{mg} / \mathrm{kg}, \mathrm{VI}=\mathrm{ATD}+$ Naringenin $40 \mathrm{mg} / \mathrm{kg}, \mathrm{VII}=\mathrm{ATD}+$ Silymarin $50 \mathrm{mg} / \mathrm{kg}$. F variance of Glutathione reductase (hepatic $=23.9^{\oplus}$, renal $=6.58^{\oplus}$ ), Glutathione peroxidase (hepatic=18.3 ${ }^{\oplus}$, renal $=9.31^{\oplus}$ ), Glucose-6-phosphate dehydrogenase (hepatic $=20.4^{\ominus}$, renal $=26.8^{\odot}$ ).

\section{Figure 3}

\section{"See image above for figure legend"}


Fig. 4.

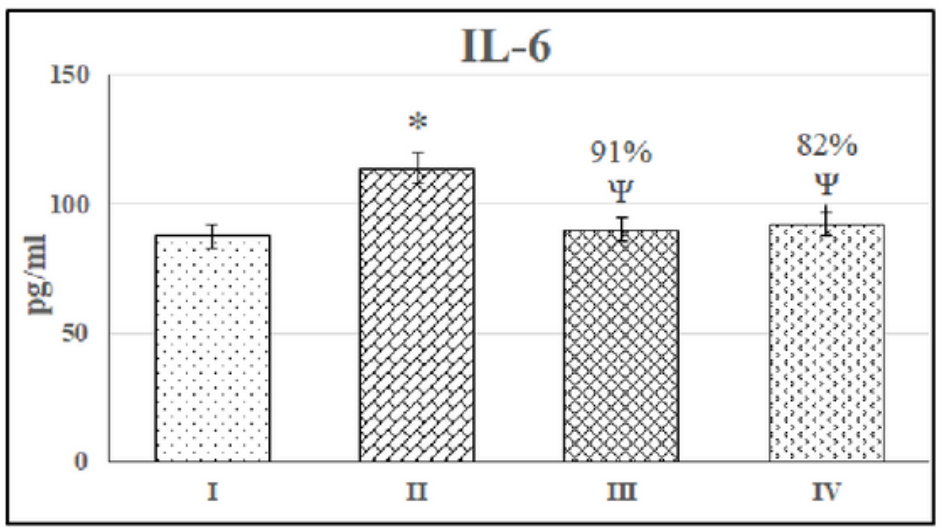

(a)

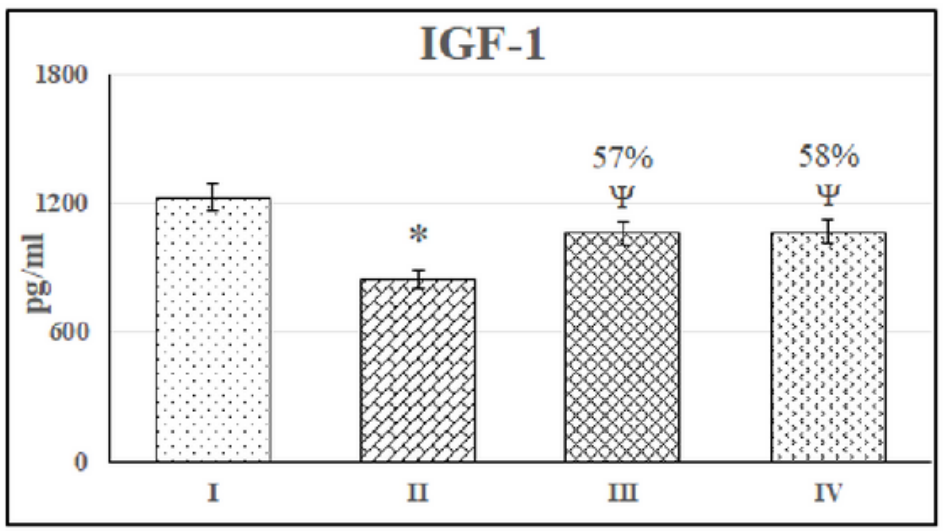

(b)

Fig. 4. (a-b). Efficacy of naringenin on ATD induced alterations in serum IL-6 and IGF-1. Data are presented as mean \pm S.E ( $n=6$ ). @ represents significant value of ANOVA at 5\%. * Control Vs ATD; ${ }^{\Psi}$ ATD Vs ATD + Naringenin (40 $\mathrm{mg} / \mathrm{kg}$ ) and Silymarin $(50 \mathrm{mg} / \mathrm{kg})$; Naringenin $(40 \mathrm{mg} / \mathrm{kg})$ Vs Silymarin $(50 \mathrm{mg} / \mathrm{kg})$ for Tukey's HSD post hoc analysis at $\mathrm{P} \leq 0.05$. ATDs represents Antituberculosis drugs. $\mathrm{I}=\mathrm{Control}, \mathrm{II}=\mathrm{ATD}, \mathrm{III}=\mathrm{ATD}+\mathrm{Naringenin} 40$ $\mathrm{mg} / \mathrm{kg}, \mathrm{IV}=\mathrm{ATD}+$ Silymarin $50 \mathrm{mg} / \mathrm{kg}$. F variance of IL-6 $\left(24.6^{\circledR}\right), \operatorname{IGF}-1\left(5.12^{\circledR}\right)$.

\section{Figure 4}

"See image above for figure legend" 
Fig. 5.
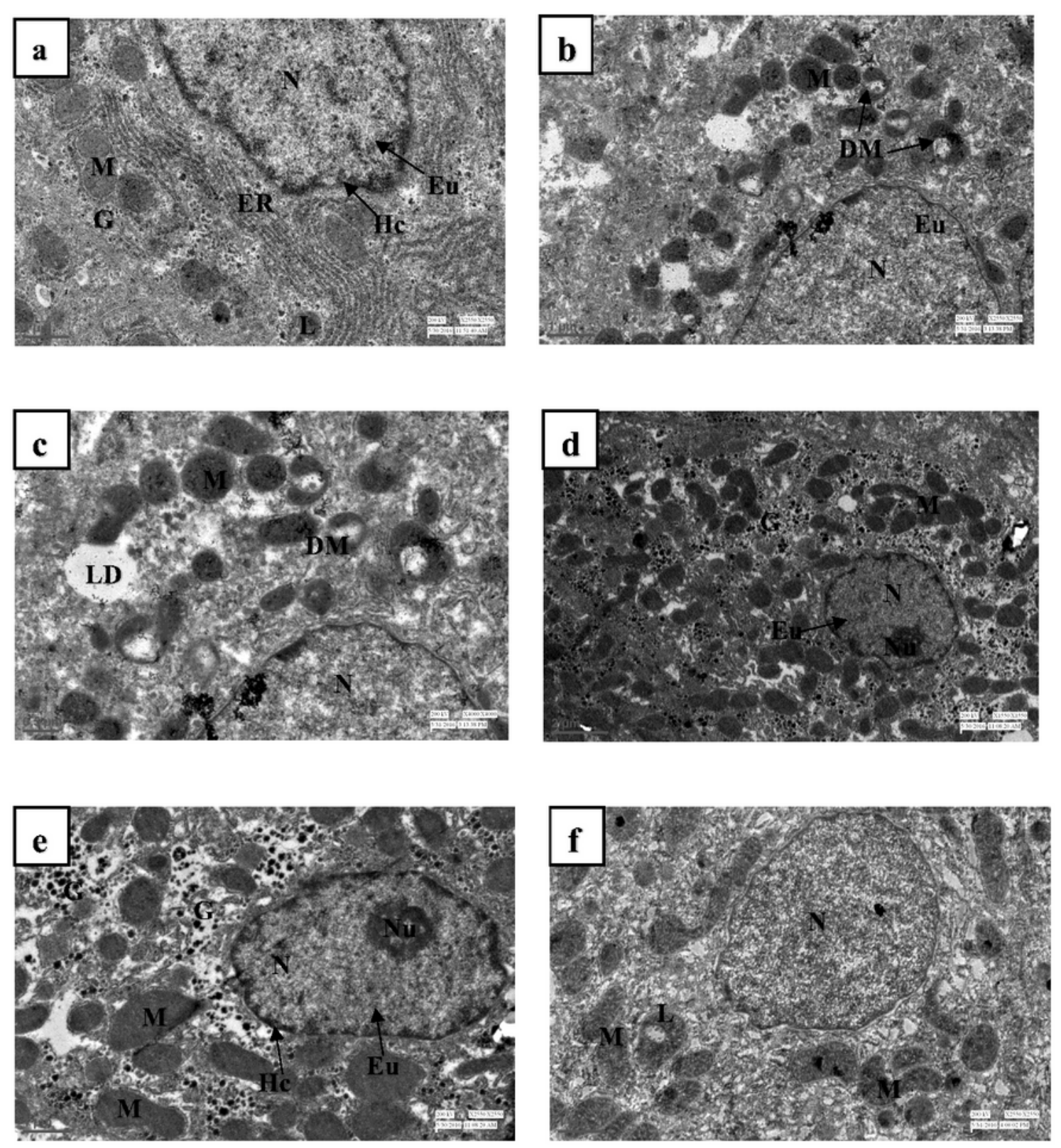

Figure 5

(a-f). Electron micrograph of liver sample, [5(a) 1500X] of control group showing numerous regular shaped mitochondria (M) of various size as well as clusters of rough endoplasmic reticulum (ER), glycogen rosettes $(\mathrm{G})$, lysosome $(\mathrm{L})$, heterochromatin $(\mathrm{Hc})$ and euchromatin (Eu). [5(b) 1500X] and [5(c) 2500X] of ATDs administered group for 8 weeks showing hepatic injury as lipid droplets (LD), damaged mitochondria (DM), congested nucleus $(\mathrm{N})$, disintegration in cytosolic matrix, less ER, nucleus with 
euchromatin (Eu) are clearly visible. [5(d) 1500X] and [5(e) 1500X] of ATDs administered group for 8 weeks with $40 \mathrm{mg} / \mathrm{kg}$ dose of naringenin showing recovery as there is almost normal hepatocytes structure with normally appeared numerous mitochondria (M), integrity in cytosolic matrix, glycogen rosettes $(G)$, heterochromatin $(\mathrm{Hc})$, euchromatin $(\mathrm{Eu})$, nucleolus and scattered ER are clearly visible. [5(f) 1500X] ATD administered rat for 8 weeks with $50 \mathrm{mg} / \mathrm{kg}$ dose of silymarin are well compared with control group having normal mitochondria $(\mathrm{M})$, lysosomes $(\mathrm{L})$, nucleus $(\mathrm{N})$ and nuclear envelop with nuclear pores.

Fig. 6.
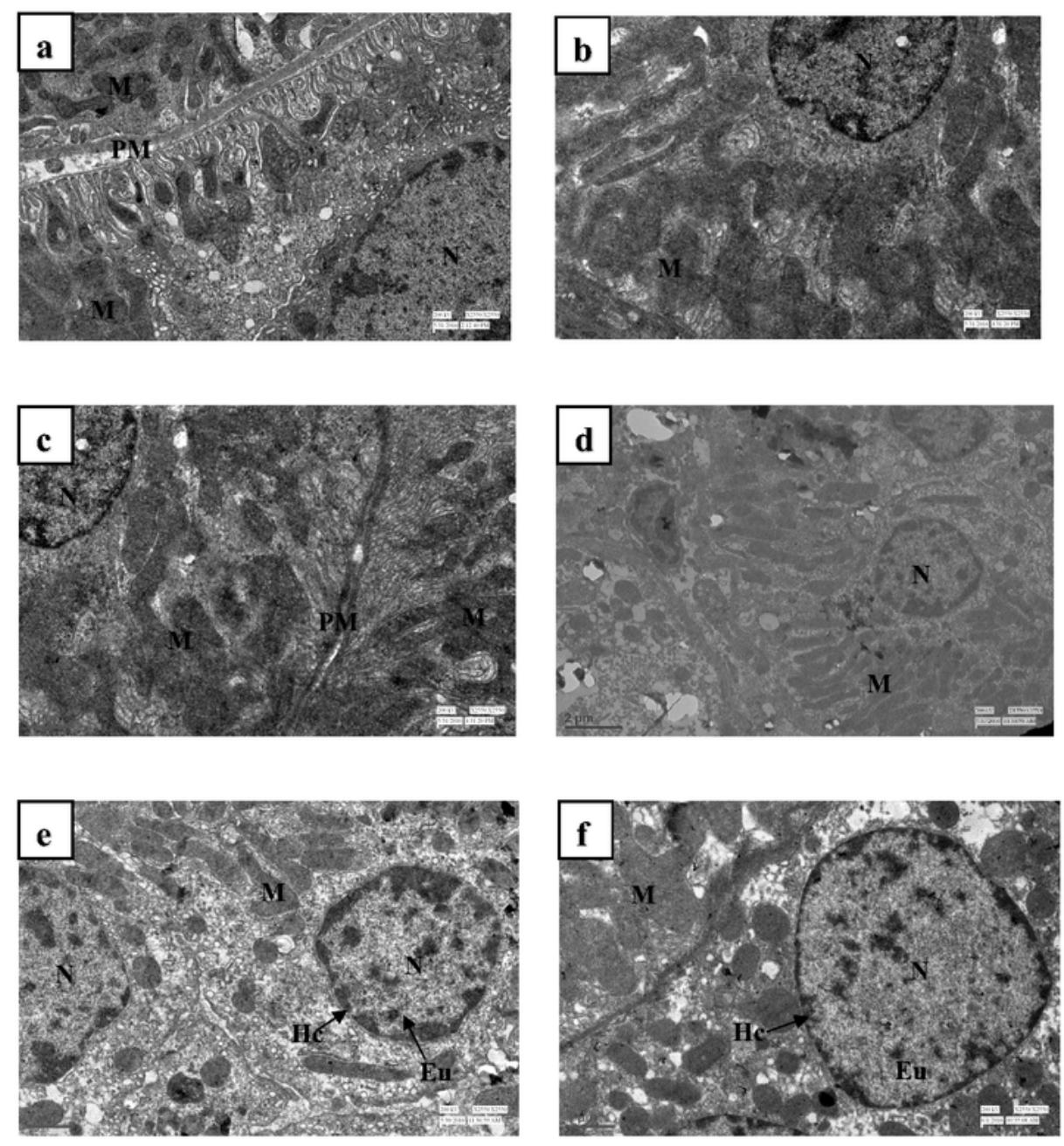


\section{Figure 6}

(a-f). Electron micrographs of kidney sample, [6(a) 1500X] of control group showing normal architecture of kidney having elongated numerous mitochondria $(M)$ in between plasma membrane (PM) undulations. [6(b) 1500X] and [6(c) 2500X] of ATDs administered group for 8 weeks showing renal damage by presence of deformed mitochondria (M), nucleus (N) and lipid droplets (LD), degenerated undulation of plasma membrane were also detected. [6(d) and 6(e) 1500X] of ATDs administered group for 8 weeks with $40 \mathrm{mg} / \mathrm{kg}$ dose of naringenin showing recovery towards control due to clearly visible mitochondria $(\mathrm{M})$ of different shapes and size, presence of nucleus $(\mathrm{N})$ with heterochromatin $(\mathrm{Hc})$, euchromatin $(\mathrm{Eu})$, and well-formed undulations of plasma membrane. [6(f) 1500X] of ATDs administered group for 8 weeks with $50 \mathrm{mg} / \mathrm{kg}$ dose of silymarin showing regeneration with well-developed nucleus $(\mathrm{N})$, plasma membrane (PM) and presence of abundant normal mitochondria (M).

\section{Supplementary Files}

This is a list of supplementary files associated with this preprint. Click to download.

- Supplementfile.xIsx 